\title{
DETERMINANTS OF TAX NONCOMPLIANCE AMONG SMALL AND MEDIUM ENTERPRISES IN KLANG VALLEY, MALAYSIA
}

\author{
Marziana Mohamad \\ College of Energy Business and Economic, Universiti Tenaga Nasional, Putrajaya, Malaysia; \\ marziana@uniten.edu.my \\ Mohd Sakarnor Deris \\ College of Engineering, Universiti Tenaga Nasional, Putrajaya, Malaysia; \\ sakarnor@uniten.edu.my
}

\begin{abstract}
The aim of this study was to identify the determinant of tax noncompliance among the small and medium enterprises (SMEs). The study also examine the perception of SME taxpayers toward tax penalty, company size and level of income. Tax noncompliance is defined as when the taxpayers did not comply or follow the tax rule and tax regulation set by the tax authority. The increasing value of tax noncompliance will affect the value of tax revenue to the government. The sample consists of the small and medium enterprises (SME) operators in distributive trade, service providers; and food and beverages in Klang Valley, Malaysia. The selected of this sectors because among the highest numbers SMEs operators. 150 questionnaires were distributed to the SME operators, only $86(55.42 \%)$ respondents' agreed to participate. Statistical Package for Social Sciences (SPSS) is using to test the reliability, normality, descriptive and correlation of the respondents. The results indicated that there is/was a number of significant relationship between company size and level of income towards tax noncompliance among the SMEs. The study recommends that Inland Revenue Board of Malaysia (IRBM) management can improve the level of tax compliance by ensuring the favorable and fair tax rates especially to SME operators
\end{abstract}

\section{Keywords: SMEs, Tax noncompliance, Tax penalty, Company size, Level of income}

\section{Introduction}

Taxation is one of the methods to finance government expenditures and the important components of government revenues to each country. It also as the main sources of a country to support the facilities and developments for all nations. Several studies stated that taxation is an amount payable required by the government to supply and provide any specific welfare or service to all citizens (Aghion, Akcigit, Cage and Ker, 2016; Spilker, Ayers, Robinson, Outslay, Worsham, Barrick and Weaver, 2013). In Malaysia, two types of taxes are imposed namely direct and indirect tax. Direct taxes included individual tax, company tax, real property tax and petroleum tax. For indirect taxes are good and services tax (GST), import duties, export duties and excise tax. The Inland Revenue Board of Malaysia (IRBM) administers direct tax and Royal Malaysia Customs and Excise Department handles indirect tax.

Based on the trend of tax collection for direct taxes between years 2010 until 2014 shows that the amount tax collection was slightly increasing year by year. However, in year 2015 and 2016, tax collection was slightly decrease (Annual Report, 2016). Given this trend, it shows that some of the taxpayers did not disclose all their total income and submitted accordingly. It called as tax noncompliance. Tax noncompliance is one of the several phenomena that have affected the global economy in developed and developing countries (Ross and McGee, 2012; Hindriks, Peralta and Weber, 2008).

Small and medium enterprises (SMEs) are the majority business taxpayers in most developing countries and impart direct impact on government revenue (Maseko, 2014). In Malaysia, National Small and Medium Enterprises Development Council (SMIDEC) categories SMEs into micro, small and medium enterprises based on the number of employees and annual turnover. In 2016, based on SMIDEC data, 76.5\% $(n=693,670)$ of the SMEs are microenterprises, $21.2 \%(n=192,783)$ are small and $2.3 \%(n=20,612)$ are medium categories of SMEs. According to Palil and Mustapha (2011) reported that SME taxpayers are lack knowledge about the level of taxable income, types of taxes of the business that supposed to pay. It also supported by Alink (2010), indicated that tax noncompliance behavior of SMEs includes non-registration for tax, non-filing of returns, none or poor payment record, underreporting of turnover and profit; and poor bookkeeping. Many SME taxpayers do not know the domain of tax professional because of lack the independence and have no tax competency (Nakiwala, 2010; European Commission, 2007). Besides that, the 
difficulties within the tax system, some of SME taxpayers involved to avoid or evade tax payable (Muharremi, Madani, Pelari, 2014; Choong, Lai and Ng, 2009).

Thus, the objective of this study is to identify the determinants of tax noncompliance among small and medium enterprises in Klang Valley, Malaysia. This study highlights three main determinants of tax noncompliance, namely tax penalty, company size and level of income.

\section{Literature review}

Tax compliance and tax noncompliance has been discussing in a major research topic in economic psychology. It is a combination between economic and psychology or non-economic determinants. Economic determinants are measured the taxpayers perception in terms of tax rate, tax audit, penalty, total income and other monetary variables. In terms of non-economic determinants are measured by the willingness of taxpayers to pay tax and to explain the behavior of tax compliance (Yong and Hooper, 2011; Hyun, Park and Ya, 2002). Some researchers have viewed tax compliance and tax noncompliance from a different perspective. For example, Allingham and Sandmo (1972) described tax compliance as reporting an actual income and claimed that tax compliance behavior influenced by a situation of taxpayers' decision. According to Alm (1991) and Jackson and Milliron (1986) defined tax compliance as the reporting of all incomes and payments of all taxes by fulfilling the tax laws, regulations and court judgment that classified as an economic approach.

On the other side, Jackson and Milliron (1986) and Alm (1999), behavior can be interpreted by the social and psychological approach. Social and psychological approach includes personal factor and social influences to measure the tax noncompliance. Tax noncompliance consists of two elements, namely tax avoidance and tax evasion (Cussia, 2010). Tax avoidance is legal activities to minimise tax payable, and tax evasion is illegal activities such as fraud or manipulated the tax payable. Tax noncompliance is defined as taxpayers' failure to remit a proper amount of tax, contradictions in the tax legislation or tax administration procedure (Kasipillai and Jabbar, 2003; Kesselman, 1994; Jackson and Milliron, 1986). Several studies reported, the choices to omit income tax are taxpayers rational decision and formulated under the policy tools, such as penalty rates, tax rate and audit rate that lead to high tax non-compliance and contribute to hidden economy (Schneider, 2012; Schneider and Savasan, 2007; Dell'Anno, 2007; Savasan, 2003).

Tax penalty is imposed to taxpayers if they failure to perform well as required by the tax authorities such as failure to timely file return or filling wrong or underreporting income (Oladipupo and Obazee, 2016). The author finding reported that tax penalty did not have significant effect on tax compliance at $5 \%$ level of significance. In Malaysia, if taxpayers involved such as underreporting or misstatement the total income that discovered during the audit process, a penalty will be imposed under subsection 113(2) of the Income Tax Act (ITA) 1967. If the firms involved in fraud or manipulate activities, tax investigation will start by the tax inspector of IRB. Based on the Annual Report 2016, reported the increasing numbers of cases audited for SME taxpayers in 2016 than the year before which are 541,798 cases compared to 529,010 cases for 2015, respectively. It is consistent with previous studies reported that the higher tax burdens to the taxpayers especially SME taxpayers have negative impact on compliance (Bello and Danjuma, 2014; Barbuta-Misu, 2011).

Company size variable also one of the determinants to measure the level of tax noncompliance. Juahir, Norsiah and Norman (2010) and Zainal Abidin, Hasseldine and Paton (2010) emphasized that the bigger the firms are, the more the firm is complaint with the tax law due to proper internal control, need a good accounting system and greater tax knowledge as compared to small firms. In a study done by Hanlon, Mills and Slemrod (2007) and Slemrod (2007), they found a positive relationship between company size and tax noncompliance. From the findings, it concluded that tax noncompliance increases as the size of the business increases. Besides that, Olorunshola (2003) explained that the ownership style has led small and medium enterprises to have a simple management structure. It is due to few numbers of employees and the owners' have a low level of education.

Besides that, the level of income also influenced the tax noncompliance. For example, once the taxpayers have decided to evade taxes, the degree of underreporting depends on the relative risk aversion. Allingham and Sandom (1972) have concluded 'that when actual income varies, the fraction of income declared increases, stays constant or decreases accordingly as relative aversion is an increasing, constant or decreasing function of income'. Alm, McClelland and Schulze (1992), also successfully proved a positive relation of income and tax compliance. In a study done by Chau and Leung (2009) also reported that the respondents in the lower-income group tend to have a lower proportion of tax compliance by underreporting income and by over claiming expenses than their counterparts in the higher-income group. Therefore, the following hypotheses are constructed:

$H_{1}$ : Tax penalty is significantly correlated to tax non-compliance

$\mathrm{H}_{2}$ : Company size is significantly correlated to tax non-compliance

$H_{3}$ : Level of income is significantly correlated to tax non-compliance 


\section{Method}

This study used survey design to analyse the perception of SME taxpayers toward tax noncompliance. Data of this study was gathered from fieldwork using questionnaire with Likert scale to determine agreement on the statements given ( 5 points Likert scale, $1=$ strongly disagree, $2=$ disagree, $3=$ not sure, $4=$ agree and $5=$ strongly agree). The questionnaire consists of two parts. The part A of the questionnaire is on the demographic characteristics of the respondents while part B of the questionnaire is on the research questions on the research variables namely, tax penalty, company size, level of income and tax non-compliance. The dependent variable of this study is level of tax noncompliance. Questions were adapted from previous studies that are Abdullah, Harry, Sazali, Qaiser and Thurai (2014) and Abdul Jabbar (2009).

A total of 150 questionnaires were distributed to the top three industries of SME taxpayers' in Klang Valley, Malaysia. The Klang Valley includes Kuala Lumpur and Selangor area. The top three industries selected are distributive trade, service providers; and food and beverages. Selected of these sectors because among the highest numbers SMEs operators. The total response rates for all three sectors are $55.42 \%(\mathrm{n}=$ 86) is presented in Table 1. This response is acceptable according to Hair, Black, Balin and Anderson (2010).

Table 1: Response rate

\begin{tabular}{cccc}
\hline Sector & Total distributed & Total completed & Response rate per sector \\
\hline Distributive trade & 113 & 64 & $56.64 \%$ \\
\hline Service providers & 23 & 17 & $73.91 \%$ \\
\hline Food and beverages & 14 & 5 & $35.71 \%$ \\
\hline Total & 150 & 86 & $55.42 \%$ \\
\hline
\end{tabular}

To ensure the reliability of the instrument, the questionnaire was pre-tested using fifteen (15) respondents. The data obtained were analysed by using Statistical Package for Social Sciences (SPSS) to test the reliability, normality, descriptive and correlation of the respondents.

\section{Results and discussion}

Reliability analysis is used to measure the data is without bias or error free and ensures consistent measurement across time and all items in the instrument (Sekaran and Bougie, 2011). The finding shows that the Cronbach alpha coefficient obtained is an equal or above 0.70 which is acceptable. The result in Table 2 represents that all research questions in the questionnaire have internal consistency.

Table 2: Reliability analysis

\begin{tabular}{lcc}
\hline Cronbach's alpha & $\begin{array}{c}\text { Cronbach's alpha based on } \\
\text { Standardised Items }\end{array}$ & No of Items \\
\hline Tax penalty: 0.821 & 0.813 & 8 \\
\hline Company size: 0.770 & 0.770 & 8 \\
\hline Level of Income: 0.695 & 0.697 & 6 \\
\hline Level of Tax non-compliance:0.721 & 0.720 & 5
\end{tabular}

Normality test is used to determine whether a data set is well modeled by normal distribution or not normal distribution. The form of Kolmogorov-Smirnov (K-S) test compares the scores in the sample to a normally distributed set of scores with the same means and standard deviation. From the findings, it shows that all variables $p$ value is more than 0.05 except the tax noncompliance variable, which is the $p$ value is less than 0.05 . From the findings, the ratio of 3 out of 4 variables the $p$ value is more than 0.05 ; therefore the data collected is normally distributed. The results are represented in Table 3.

Table 3: Normality analysis

\begin{tabular}{lccc}
\hline & \multicolumn{3}{c}{ Kolmogorov - Smirnov a } \\
\hline Statistic & df & Sig. \\
\hline Tax penalty & 0.084 & 86 & 0.198
\end{tabular}

Submit Date: 10.07.2018, Acceptance Date: 22.08.2018, DOI NO: 10.7456/1080SSE/173

Research Article - This article was checked by Turnitin

Copyright $\mathbb{C}$ The Turkish Online Journal of Design, Art and Communication 
The Turkish Online Journal of Design, Art and Communication - TOJDAC ISSN: 2146-5193, September 2018 Special Edition, p.1293-1299

\begin{tabular}{lccc}
\hline Company size & 0.079 & 86 & 0.200 \\
\hline Level of income & 0.088 & 86 & 0.097 \\
\hline Tax non-compliance & 0.187 & 86 & 0.000
\end{tabular}

Descriptive analysis has been utilised to explain the profile of respondents regarding both demographic information of SME taxpayers, namely age, gender, position, numbers of employees and annual turnover. The analysis revealed that the majority of respondents were aged between 21 to 30 years $(40.7 \%)$, while 25.6 percent of the respondents were between 31 to 40 years old. In respect of the gender, it is show an equal responses rate which is 50 percent for both male $(n=43)$ and female $(n=43)$, respectively. Then, in terms of SME taxpayers' position, the majority of the respondents were senior $(43 \%)$, followed by junior $(25.6 \%)$, manager $(22.10 \%)$, partner $(8.1 \%)$ and others $(1.2 \%)$. Based on the number of employees, it has divided into SME categories, which are micro, small and medium. The highest percentage is small categories (53.5\%), followed by medium categories $(29.1 \%)$ and micro categories (17.4\%). Lastly, in terms of annual turnover, the highest percentage of the respondents is below RM300,000 (41.9\%), followed by annual turnover between RM300,001 to RM3,000,000 (40.7\%) and annual turnover between RM3,000,001 to RM20,000,000 $(17.4 \%)$.

Table 4 shows the level of SMEs perception on tax penalty. Some of the respondents agreed with the statement of "cost to hire expertise to handle tax compliance is higher than the penalty rate imposed". Majority of the respondents are not sure with the current penalty rate imposed by the IRB to the noncompliance taxpayers. Besides that, they also are not sure either the higher tax penalty will result a good of tax compliance.

Table 4: Perception on tax penalty

\begin{tabular}{lc}
\hline Questions & Mean \\
\hline The current penalty rates are fairly charged & 2.6395 \\
\hline Higher penalty rate will result in betterment of tax compliance & 2.6977 \\
\hline $\begin{array}{l}\text { The current penalty rate imposed by the Inland Revenue Board (IRB) is } \\
\text { efficient enough to ensure higher level of tax compliance }\end{array}$ & 2.8488 \\
\hline $\begin{array}{l}\text { If penalty rates are not imposed, there will be proper tax compliance } \\
\text { practiced }\end{array}$ & 2.9767 \\
\hline \begin{tabular}{l} 
The penalty rate should be lowered if the tax payable is below certain amount \\
\hline Tax noncompliance should give a strict punishment to taxpayers
\end{tabular} & 3.1860 \\
\hline \begin{tabular}{l} 
Your firm rather choose to pay the penalty than to comply with the tax law \\
\hline $\begin{array}{l}\text { Cost to hire expertise to handle tax compliance is higher than the penalty rate } \\
\text { imposed }\end{array}$
\end{tabular} & 2.948538 \\
\hline
\end{tabular}

Results in Table 5 shows the perception of SME taxpayers toward company size. Some of the respondents disagreed with the statement of "smaller firms do not have sufficient expertise to handle tax compliance". On the other hand, majority of the respondents are not sure either the small firms are more likely to escape from tax noncompliance compared to larger firms.

Table 5: Perception on company size

\begin{tabular}{lc} 
Questions & Mean \\
\hline Number of employees of the firm affects the efficiency of the tax compliance & 3.4070 \\
\hline Capital structure of the firm affects the efficiency of tax compliance & 3.2907 \\
\hline $\begin{array}{l}\text { Smaller firms can option out, not to comply with tax requirements as IRB places less focus } \\
\text { on these firms }\end{array}$ & 3.3721
\end{tabular}


The Turkish Online Journal of Design, Art and Communication - TOJDAC

ISSN: 2146-5193, September 2018 Special Edition, p.1293-1299

Larger firms can option out, not to comply with tax requirements

Smaller firm's do not have sufficient expertise to handle tax compliance

Organization culture in both large and small firms plays an important role in tax 3.3372 noncompliance

Small management composition result in lower compliance to the tax requirement

Small firms are more likely to escape from the tax noncompliance compared to larger firms

Correlation analysis is used to investigate the correlate of all independent variables towards dependent variable. The Pearson correlation analysis is used to test hypothesis $1\left(\mathrm{H}_{1}\right)$, hypothesis $2\left(\mathrm{H}_{2}\right)$ and hypothesis $3\left(\mathrm{H}_{3}\right)$. The results in Table 6 revealed that the hypothesis $2\left(\mathrm{H}_{2}\right)$ and hypothesis $3\left(\mathrm{H}_{3}\right)$ are supported because the significant relationship is less than 0.05 at the level of significance. Firstly, in terms of tax penalty variable, the correlation value is 0.205 which represented that there is no significant relationship between the tax penalty and tax noncompliance. The $\mathrm{p}$ value is more than 0.05 , which is 0.058 . The finding is consistent with the previous studies, reported by Oladipupo and Obazee (2016). Therefore, hypothesis $\left(\mathrm{H}_{1}\right)$ is not supported.

Secondly, in term of company size, the finding shows that there is a significant relationship between company size and tax noncompliance. The correlation value is 0.227 , which represented an average significant relationship with the $\mathrm{p}$ value is 0.035 . This study is in line with the finding reported by Hanlon et. al., (2007) and Slemrod (2007). The finding proved that have positive relationship between company size and tax noncompliance. Therefore, hypothesis $\left(\mathrm{H}_{2}\right)$ is supported. Thirdly, in terms of level of income towards tax noncompliance, the result show that there is a significant relationship between level of income and tax noncompliance. It is represented the annual income have an effect toward tax noncompliance among the SME taxpayers. The correlations value is 0.216 with the significant value is less than 0.05 , which is the $p$ value of 0.46 . The finding also consistent with the previous studies that verified a positive relation of income and tax compliance (Chau and Leung, 2009; Alm et al, 1992). Therefore, hypothesis $\left(\mathrm{H}_{3}\right)$ is supported.

Based on the classical author, which is Allingham and Sandmo (1972) stated that the decision to comply or not to comply is come from the taxpayers itself. Table 6 represented the level of overall tax noncompliance among SMEs respondents.

Table 6: Correlation Coefficients

\begin{tabular}{lllll} 
& TNON & TAXPEN & SIZE & INCOME \\
\hline TNON & 1.000 & 0.205 & $0.227^{*}$ & $0.216^{*}$ \\
\hline TAXPEN & 0.205 & 1.000 & $0.575^{* *}$ & $0.536^{* *}$ \\
\hline SIZE & $\mathbf{0 . 2 2 7 *}$ & $0.575^{* *}$ & 1.000 & $0.420^{* *}$ \\
\hline INCOME & $\mathbf{0 . 2 1 6 *}$ & $0.536^{*}$ & $0.420^{* *}$ & 1.000 \\
\hline \multicolumn{5}{c}{ ** Significant at 1\% level } \\
& * Significant at 5\% level
\end{tabular}

\section{Conclusions}

From the findings, it was shown that the various determinants that affect tax noncompliance were significant. As we know, tax noncompliance is a serious phenomenon to many tax authorities. In other word, it is not an easy work to persuade taxpayers followed or comply the tax law and regulations.

Based on the findings, company size and level of income have positively influenced the level of tax noncompliance. In terms of descriptive analysis, the overall finding on the perceptions of SME taxpayers towards tax penalty, company size and level of income is an average sensitivity. Some of SME taxpayers are agreed and not sure the tax system applied. For example, some of the respondents' are not sure the specific tax penalty rate entitled for those who are non-comply with tax rule and tax regulation.

Therefore, all parties are responsible to reduce the level of tax noncompliance. The increasing value of tax noncompliance will lead to reduce the tax collection every year. The tax authorities and tax firms need to organise and handle more training and education program especially to SME taxpayers. In other words, IRB should offer the favorable and fair tax rate to SME operators. However, this study cannot be generalized to all sectors and other area located in Malaysia.

\section{Acknowledgment}

Submit Date: 10.07.2018, Acceptance Date: 22.08.2018, DOI NO: 10.7456/1080SSE/173

Research Article - This article was checked by Turnitin

Copyright (C) The Turkish Online Journal of Design, Art and Communication 
The Turkish Online Journal of Design, Art and Communication - TOJDAC

ISSN: 2146-5193, September 2018 Special Edition, p.1293-1299

This study received the research funded by the Ministry of Higher Education Malaysia (MOHE). We would like to thank to MOHE for giving us the financial support that is under Fundamental Research Grant Scheme (FRGS). Also to our university to provide us the facilities to finish this project.

\section{REFERENCES}

Abdul Jabbar, H. (2009). Income tax noncompliance of small and medium enterprises in Malaysia: Determinants and tax compliance costs. Unpublished doctoral dissertation, Curtin University of Technology, Perth, Australia.

Abdullah, A.M., Harry, E., Shazali, A.M., Qaiser, R.Y., Thurai, M.N. (2014). The impact of Demographic factors on tax compliance attitude and behavior in Malaysia. Journal of Finance, Accounting and Management, 5(1): 109-124.

Aghion, P., Akcigit, U., Cage, J., and Ker, W. R. (2016). Taxation, corruption and growth. European Economic Review, 86: 24-51.

Alink, M. (2010). Looking beyond the border: Recent developments in micro and small business taxation in others regions. Presentation at the OECD Conference on Taxing Micro and Small Business, Manila.

Allingham, M.G., and Sandmo, A. (1972). Income tax evasion: A theoretical analysis. Journal of Public Economic, 1 (3-4): 323-338.

Alm, J. (1991). A perspective on the experimental analysis of taxpayer reporting. The Accounting Review, 66(3): 577-593.

Alm, J., McClelland, G., and Schulze, W. (1992). Why do people pay taxes? Journal of Public Economic, 48(1): 21-38.

Barbuta-Misu, N. (2011). A review of factors for tax compliance. Economics and Applied Informatics, 17(1): 69-76.

Chong, K.F., Lai, M.L. and Ng, K.T. (2009). Hawkers and the self-assessment system tax system: Survey evidence from Malaysia, Oxford Journal, 8 (1): 119-132.

Cuccia, A.D. (2010). The effects of increased sanctions on paid tax preparers integrating economic and psychological factors. The Journal of the American Taxation Association, 16(1): 41-66.

DellAnno, R. (2007). The shadow economy of Italy and other OECD countries: What do we know? Journal of Public Finance and Public Choice: 1-31.

Hair, J.F., Balck, W.C., Balin, B.J., and Anderson, R.E. (2010). Multivariate data analysis: Maxwell Macmillan International Editions.

Hanlon, M., Mills, L., and Slemrod, J. (2007). An empirical examination of corporate tax noncompliance. In A. Auerbach, Hines, J.R., and Slemrod, J. (Ed.), Taxing Corporate Income in the 21st Century. Cambridge: Cambridge University Press: 171-210.

Hindriks, J., Peralta, S., and Weber, S. (2008). Competing in taxes and investment under fiscal equalization. Journal of Public Economics, 92(12): 2392-2402.

Jackson, B.R., and Milliron, V.C. (1986). Tax compliance research: Findings, problem and prospects. Journal or Accounting Literature, 5: 125-165.

James, S., and Alley, C. (2002). Tax compliance, self-assessment and tax administration. Journal of Finance and Management in Public Services, Vol. 2, No. 2: 27-42.

Juahir, M.N., Norsiah, A., and Norman, M.S. (2010). Fraudulent financial reporting and company characteristics: Tax audit evidence. Journal of Financial Reporting and Accounting, 8 (2): 1985-2517.

Kasipillai, J., and Jabbar, H.A. (2003). Tax compliance attitude and behavior: Gender and ethnicity differences of Malaysia taxpayers. Malaysia Accountant. February: 2-7.

Kesselman, J.R. (1994). Compliance, enforcement and administrative factors in improving tax fairness in Maslove. A.M. (Ed) Issues in the Taxation of the individual. Queen' Printer Ontario: 62-84.

Maseko, N. (2014). Determinants of tax compliance in small and medium enterprises in Zimbabwe. Journal of Economics and International Business Research, Vol. 2(3): 48-57 
The Turkish Online Journal of Design, Art and Communication - TOJDAC

ISSN: 2146-5193, September 2018 Special Edition, p.1293-1299

Muharremi, O., Madani, F. and Pelari, E. (2014). Tax evasion and set backs of the shadow economy in Albania. Mediterranean Journal of Social Sciences, MCSER Publishing, Rome-Italy, V. (5), No. 13:398-408

Nakiwala, A. (2010). Tax competencies, compliance cost and income tax compliance among SMEs in Uganda: Master Dissertation.

Oladipupo, A.O., and Obazee, U. (2016). Tax knowledge, penalties and tax compliance in Small and Medium Scale Enterprises in Nigeria. iBusiness, 8: 1-9.

Palil, M.R., and Mustapha, A.F. (2011). Factors affecting tax compliance behavior in self-assessment system. African Journal of Business Management, 5(33): 12864-12872.

Ross, A.M., and McGee, R.W. (2012). Attitude towards tax evasion: A demographic study of South African attitudes on tax evasion. Journal of Economics and Economic Education Research, 13(3): 13-58.

Savasan, F.(2003). Modelling the underground economy in Turkey: Randomized response and MIMIC Models. The Journal of Economics, Vol. XXIX (1):49-76

Schneider, F. (2012). Tax evasion in Europe. The shadow economy and tax evasion: What do we know? CESifo Forum

Schneider, F., and Savasan, F. (2007). Dymimic estimates of the size of shadow economics of Turkey and of her neighbor countries. International Research Journal of Finance and Economics, 9, 126-144.

Sekaran, U., and Bougie, R. (2011). Research method for business: A skill-building approach. John Wiley \& Sons Inc.

Slemrod, J. (2007). Cheating Ourselves: The Economics of tax evasion. Journal of Economic Perspectives, Vol. 21, No.1 Winter: 25-48.

SME Corp. Malaysia. (2015). http://www.smecorp.gov.my/index.php/en/pocies/20151221090949/smestatistic

Spilker, B., Ayers, B., Robinson, J., Outslay, E., Worsham, R., Barrick, J., and Weaver, C. (2013). McGrawHill's Taxation of Individuals and Business Entities. 2013 Edition. New York: McGraw-Hill.

The IRBM, Annual Report. (2016), Inland Revenue Board Malaysia. http://lampiran2.hasil.gov.my/pdf/ pdfam/annual report_2016.pdf

Zainal Abidin, M.Y., Hasseldine, J., and Paton, D. (2010). An analysis of tax noncompliance behavior of small and medium sized corporation in Malaysia. International Tax Administration: Building Bridges. Sydney: CCH Australia Limited: 9-24. 